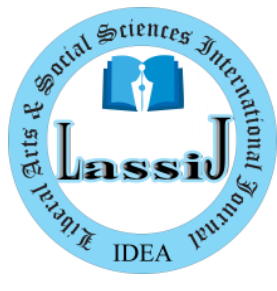

Research Article
ISSN: 2664-8148 (Online)

Liberal Arts and Social Sciences

International Journal (LASSIJ)

https:// doi.org/10.47264/idea.lassij/3.2.19

Vol. 3, No. 2, (July-December) 2019, 169-184

https://www.ideapublishers.org/lassij

\title{
Psychological Factors Influencing the Adoption of Web-Based Shopping Behaviour of Female Consumers
}

\author{
Komal Mehreen*, Robina Roshan \& Mamoona Gul \\ Department of Communication and Media Studies, Gomal University Dera Ismail Khan Pakistan.
}

\begin{abstract}
Online shopping is one of the latest emerging and revolutionary trends influencing the lives of common people. This research paper examines the relationship between demographic variables and internet exposure which are independent variables with the dependent variables i.e. psychological factors and consumer online buying behaviour. People are now moving from conventional shopping towards web based/online shopping because of which they can buy everything from home. The research paper explains the influence of five psychological variables such as security issues, privacy issues, overcharged, fraud/ hackers and lack of trust over the retailer derived from literature. Data from a sample of 298 female students of public and private sector universities of Dera Ismail Khan were collected through the self-developed and standardized questionnaire. Data were analysed by using descriptive statistics and Pearson's correlation. The statistical analysis of the data reflects a lack of trust over the retailer and privacy concerns are considered as the most relevant factors affecting female consumers' online buying behaviour.
\end{abstract}

Keywords: E-commerce \& Consumer Psyche, Web-based Shopping, Online Shopping, Privacy Issues, Overcharging, Fraud \& Hacking, Lack of Trust on Retailer.

\section{Introduction}

Nowadays the Internet has become a crucial part of our lives. The emergence of the internet completely changed the way of communication, entertainment, education, and most importantly it brings an incredible revolution in the field of marketing and advertising. Now masses are moving from traditional ways of advertising such as print media, radio, and television to new media technologies such as smart telephones, computers, and iPods, etc. Ancient civilizations are the basics of modern-day advertising. Advertising based on magazines and newspapers became a major focus in the $19^{\text {th }}$ century for the capitalist economies. Advertising was then modernized by the latest technologies like email, television, radio, internet, and mobile devices in the $20^{\text {th }}$ century. The internet has emerged as a huge marketplace globally for buying and selling services and goods in the recent couple of decades. Because of the massively increasing internet use for marketing and communication with consumers, the field of E-commerce and online buying is promptly growing day by day. In this time and age E-commerce has become a very influential marketing tool in the business world. The study of consumer's online shopping behaviour (online/internet buying behaviour) 
describes certain procedures of buying different consuming items and services using social media. The subject "consumer behaviour" is explained by various schools of thoughts of different disciplines like psychology, sociology, social anthropology, marketing, and behavioural economics which investigates customer's individual characteristic including demographics, lifestyle, cultural values, social traditions, and subjective norms which influence the buying behaviour of masses.

At presently we observe that emergence of the latest technologies greatly affect consumers buying behaviours. In the past masses are strongly bonded with a certain product and brand to gratify their needs and they only switch from those products if they feel unsatisfied and this switching behaviour is rapidly increasing because of today's competitive market that uses numerous tools and techniques to influence consumer buying behaviours. This study explores new emerging trends in female consumers' life regarding online shopping. This research focuses on female behaviour regarding online shopping to realize their attitudes and preferences, purchasing perspective of consumers who prefer E-commerce to buy different products to gratifying their needs. The study aims to understand the psychological factors which influence female consumers' behaviour. Indirectly this study will explore the popularity of E-commerce which is gaining roots among female consumers. In this paper growing trends of E-commerce and Consumer psyche especially the female consumers are analyzed. The study includes all the Private and Public Sector Universities female consumers' behavior toward ecommerce and the main focus is on some of the psychological factors such as security issues, privacy issues, overcharged, fraud/hackers, and lack of trust over the retailer that influenced the adoption of web based/online shopping behavior of female.

The present research paper is unique in the way that it explores trends of e-commerce among female consumers. It can be noticed that the behaviour of consumers towards online purchasing is greatly influenced by a variety of features like a person's privacy, product standard, security, and different risks related to online shopping, etc. This study explores techniques that will be helpful for advertisers to attract the potential consumer to become their customer in the future, the present study is very significant for advertisers and sponsors to understand consumer psyche and the impact of different online advertising strategies on consumers buying behaviour. The study is also very helpful for consumers to understand different ways of getting information about the product of their interest to gratify their needs by using the internet. Objectives of the present study are:

- To investigate the difference between demographic variables i.e., age, income, residential status, education, marital status, and online shopping behaviour of the female student.

- To investigate the exposure of using internet.

- To explore and investigate the purpose/reasons for using different sites of social media.

- To explore the time spent / frequency of watching advertisements operating different social media sites.

- To investigate psychological elements that are responsible for influencing female shoppers' online buying behaviour.

Through this research paper researcher explores new trends of shopping because of the uncertain situation of Dera Ismail Khan by this study female consumer become aware of different alternatives to shopping. The study is very significant because it will add the latest information and knowledge about female consumer buying behaviour towards web based 
shopping and it became documental proof for future researchers. In the present study following hypothesis are investigated:

H1: There is a significant relationship between demographics (age, income, residential status, education, marital status, language) of the female respondents and their online buying behaviour.

$\mathrm{H} 2$ : Higher the exposure of internet, higher will be its impact on female consumers' online shopping/buying behaviour.

H3: There is a significant relationship between psychological elements and female consumers' online buying behaviours.

While defining the various terms used in the study: a) the 'Consumer Demographic Variables' include gender, age, race/ethnicity, life stage, birth era, household size, marital status, income, education and occupation; b) the 'Psychological Factors' include individual-level processes and meanings that influence mental states; and c) the 'Consumer Buying Behaviour' refers to the actions taken (both on and offline) by consumers before buying a product or service. This process may include consulting search engines, engaging with social media posts, or a variety of other actions.

\section{Review of Literature}

Chen (2009) stated that currently in the area of e-commerce basic reason of investigation is to gain insight into consumer's online buying behaviour. Pavlou (2003) explained the relation present between consumer adoption of e-commerce and different internal and external factors affecting their behaviours. The Theory of Planned Behaviours by Ajzen (1991) explains that consumer behaviour was greatly influenced by the normative beliefs, subjective norms and attitudes, which affect their intention of purchasing certain product or service. Solomon, 2002 stated that in order to fulfil the needs of the consumers, marketers first have to understand and also analyse consumers cultural, social and behavioural beliefs toward certain product and services. The history of new media such as internet and e-commerce is short as compared to traditional media such as print, television and radio in terms of time, but presently it become the most powerful and influential medium of entertainment, information, education and advertising etc. Today, internet becomes an essential part of our day to day life activities. But now due to increasing number of companies in market the history of internet and e-commerce is still changing. New companies are emerging in order to gratify people's needs and wants thus the history of social media is still evolving.

\subsection{Internet Use}

Akin-Adaeamola (2014) argued that internet users receives great deal of information about the world. It is one of the most important platform for different types of information and awareness. It is used by students of different educational levels. According to Akende and Bamise (2017) the use of computer and availability of online resources are very important for students.

\subsection{Online Advertising}

The term online advertising can be defined as advertising using internet or internet advertising. Now days this is most influential and growing marketing trend in the business world where most of the business owners are using this internet marketing to promote their services and 
products the main objective of online marketing/advertising if to get consumers to a place, a website or to make an enquiry through phone call or email etc. about services or products as defined by enterpreneure.com (2008). From this definition it can be concluded that the major aim of internet marketing is to get the focus of a large number of consumers for a company's services and product.

\subsection{Online Shopping and Online Stores}

According to Novak and Hoffman (1999) one of the vital distinguishing characteristics between marketing interaction on the social media and traditional media is interactivity because now days consumers of e-commerce have more bargaining power and control than buyers of physical stores because the Internet provide all kind of necessary information with reference to the products and services available for the online buyers. According to Geissler and Zinkhan (1998) the balance of power was transferred by the internet in favour of buyers from the product/service providers as it gave more opportunities to the buyers to compare different products from the different suppliers by just using their phone or laptop and without any emotional pressure by the person selling products. The transaction cost is also diminished by the online stores and is useful for both, suppliers and buyers.

\subsection{Goals of Online Advertising}

Gardener and Trivedi (1998) explains that the main goal of advertising is to highlight and publicize the product or services and inform the target consumer about different features of the product or services. Goldsmith and Lafferty (2002) explains that online advertising is very important for creating brand awareness in the target audience and its basic goal of advertising is to develop positive attitude among consumers regarding advertised product which ultimately motivates them to buy certain product. It advocates that there is a need for the development of indisputable attitude of the customer towards product and advertisement as well. Ads must be according to user's interest. Advertisements appearing more often in front of the users on a websites cause the decrease in user's interest in that product/service and as a result the internet user will start ignoring the ads.

\subsection{Psychological Factors}

The psychological components include different security issues and privacy concerns that may affect the consumers' online buying behaviour. Huddleston and Lee (2010) argue that the risk about privacy is related to dissemination of personal data since online shoppers must enter their private details during shopping through internet. Chen (2010) argue that the privacy concerns must be eliminated by privacy controls of people doing online shopping. According to Nazir (2012) the factors influencing the consumer behaviour of Pakistan regarding shopping online. The study revealed that psychological, social, privacy and emotional factors had a notable influence on the buyer's behaviour doing online shopping. Security, privacy, and trust issues were some main issues faced online buyers, as identify by the research study.

Stated in the study, the reason customers don't like to do online shopping is that they are not sure about the security of their financial transactional data such as credit card details etc. Ashfaq and Rehman (2011) also explore the causes that stop Pakistani consumers to shop online. The result shows that social factors, psychological factors, emotional concerns and privacy issues greatly influence consumer's online buying behaviour. According to Sulaiman 
et al. (2007) the buyers had less trust towards online merchant dizers privacy controls because most of the time consumer's profiles were used by other parties for different marketing purpose and when they came to know this it will create mistrust in them and prevent them for making any online transactions.

\subsection{Types of Social Media}

Facebook, Instagram, Pinterest, Twitter and WhatsApp are the most regularly surfed social media websites by users for different purposes. Some use them in their spare time and some for business purposes. Miller and Lammas (2010) mentioned that more than $70 \%$ of 11 million social media users are using these sites purchase different types of products and services, to share information about certain things and gather reviews. Scott, 2013 mentioned that only Facebook has more than 6 million users who signed up just to share information about products or to purchase them. Moreover, Parson (2013) stated that around 60\% of Facebook consumers believe that they are more likely to recommend a service of a product to their surroundings after seeing the brand on Facebook. Miller and Lammmas (2010) mentioned that Twitter has reached to the magical number of 0.8 million users who gave positive reviews about the products and services provided. In another study by Parson (2013) around 79\% of Facebook consumers believe that they are more likely to recommend a service or product to their friends circle after seeing the brand on twitter or other social media websites. Instagram is getting fame globally especially in the last two years because of the users having obsession to share their day-to-day life activities in the shape of photos.

Gonzalez (2013) stated in an interview which was conducted to take his views about the fast growth in the ratio of users on Instagram; that the number of users who login daily in more or less 65 countries around the globe have increased in the last two years to 0.1 billion. Zara (2013) states that the newest addition of in the social media world is Pinterest. Pinterest, launched in 2010 is a Virtual Pinboard, enables its users to share images and websites they want to share and users can also get images from there. Steelhouse (2012) conducted a survey on social shopping that indicated that this trend will continue in future. That survey result also states that about 59\% of the Pinterest users bought a products via the Pinterest. Acton and Koum (2014), the founding developers of WhatsApp, stated that WhatsApp now became world's most popular mobile communication application. Cotton (2013) stated that WhatsApp plays an important part in the field of electronic shopping now users can send and receive text messages, pictures and also video and audio files to one another using this internet basedcommunication application.

\section{Research Methodology}

A systematic analysis of certain material used, methods, techniques and theoretical approached applied has been done for this study as follows:

\subsection{Research Design}

The researcher adopted the cross-sectional survey method in which the data is collected from the target population or representative subset through questionnaire in a specific period of time. This research highlights the different psychological factors effecting online buying behavior of the female consumers. 


\subsection{Parameters/Variables Studied}

Independent variables of the studies are:

- Demographics i.e., age, income, residential status, education, marital status.

- Exposure to internet

Dependent variables of the studies are:

- Psychological factors.

- Online buying behavior

\subsection{Limitations of the Study}

This research paper is limited to female respondents only. The term Electronic commerce or E-commerce refers to the electronic purchasing and selling of the product using internet. It is very vast field which include Retails services, Online goods and services and Market place services including different forms and areas of advertising but due to the time limitation research is limited to only online advertisements and its effects on female students buying behaviour of private and public Universities of Dera Ismail Khan.

\subsection{Instrument of Data Collection}

The present phenomena are investigated through close ended questionnaire in which five point Likert is used by the researcher for all the dependent and independent variables, questionnaire from previous researches on the same/relatively same topic was developed by merging different adapted questions to make it suitable for the present study and utilized by the researcher to gather the relevant data from the respondents.

\subsection{Population}

Population is anything that comes in the radar of the study. Population of this research is one private and one public sector university, Qurtuba University, and Gomal University in D. I. Khan, Pakistan. Universities were selected in view of the time frame and suitability.

\subsection{Sampling Technique and Procedure}

There are many types of sampling strategies but for the present work research used probability sampling or simple random sampling technique according to this technique each individual in the population have an equal chance to be chosen as a part of sample. It is the fairest way of selecting the sample without any favoritism.

\subsection{Sample size}

For this research, the sample has been selected through multi stage sampling procedure because of the limited resources. Since the total female population of two universities selected by the researcher for this research, the Gomal University and Qurtuba University, was between 1001 to 5000 and 101-1000 respectively. Therefore, researchers used Curry and Dr. John's formula to draw sample size from the population. Details of the total population and sample size selected from it after applying 5\% formula is as under: 


\begin{tabular}{|l|c|c|c|}
\hline Universities & $\begin{array}{c}\text { Total Female } \\
\text { Population }\end{array}$ & $\begin{array}{c}\text { Curry, Dr. John } \\
\text { Formula }\end{array}$ & $\begin{array}{c}\text { Sample Size Selected } \\
\text { from that College }\end{array}$ \\
\hline Gomal University D. I. Khan & 4425 & $5 \%$ & 221 \\
\hline Qurtuba University D. I. Khan & 767 & $10 \%$ & 77 \\
\hline \multicolumn{2}{|c|}{ Total } \\
\hline
\end{tabular}

\subsection{Validity and Reliability Test}

To measure whether the problem statement and questions includes in the questionnaire are accurately measure the variables which are under observation in this study, in the process of validity the first step is to view the problem statement and questionnaire under the light of previous literature after that the initial draft of the questionnaire will be given to the facility members of the Department of Communication and Media Studies at Gomal University, Dera Ismail Khan, thus the well-constructed and rational questionnaire was then proceeded to check reliability. Another step is reliability check to measure the accuracy and consistency of the questions included in the final questionnaire. Present research paper used descriptive statistics Mean and Standard deviation for different variables, One way ANOVA, T-Test and Pearson's correlation to measure the internal consistency of the variables.

\subsection{Research Model/Framework}

This research is based on Planned Behaviour Theory which explains the basic elements of the reasoned action including perceived control of the behaviour, subjective norm and intentions influencing the behaviour of customers. Pavlou and Fygenson (2006) explains the customer's usage of e-commerce with the extended Theory of Planned Behaviour (TPB). Results of Ajzen (1991) shows that purchasing behaviour and getting information behaviour were greatly affected by the characteristics such as consumer's trust, attitude, risks, social factors, skills to browse the internet, and technology-oriented factors that include recognized ease of use and features of the website, recognized usefulness etc. TPB (planned behaviour theory) is implemented to check the significance of different social and technological based factors which are playing crucial role in construction of certain the behaviours in female respondents regarding online purchasing. Fishbein and Azjen (1980) proposed the Theory of Reasoned Action (TRA) explaining the behaviour of humans according to the theory human behaviour is leaded by aims; build on consumers' viewpoint about certain attitude and on recognized subjective standard things. Attitude shows someone's unfavourable or favourable feelings about some obvious behaviours. Subjective norms like peers, family, media, and authority figures also take significant part in influencing buyer's behaviour.

$\mathrm{Yu}$ and $\mathrm{Wu}$ (2007) argue that one of the key factors in influencing the buying behaviour of the customer is online retailers. In the present study researcher applied the theory of reasoned action to analyses the factors which are influencing the perceptions of female consumers regarding online shopping. Computer Mediated Communication (CMC) is the method of developing, exchanging and processing the given data or info, to encode then decode and finally transmitting or communicate the information using network of telecommunication. It also includes all type of human communication such as character-based facilitated or directed through the digitally-based technologies. It includes the Internet; electronic mail (email), instant messaging, cellular phone text, multiuser interaction etc. In this definition, certain message interchange is computerized at certain point in the medium of exchange when people are involved in the process. 
Some of the communications are not considered as CMC, like hearing ads, megaphones or dedicated analogue teletype systems and also electronically enhanced or enabled systems. In addition, computers are not usually included by various media's, since digital technologies are involved by lots of media. In this research work researcher applied the theory of computer mediated communication to check the significance of advance technology which are affecting each aspect of human life. This theory strengthen the present study as it explains the importance of technology based communication of information, entertainment, marketing etc. and how these technologies are affecting day to day life affairs including shopping habits.

\section{Results and Discussion}

Data was analyzed through an application called SPSS which stands for Statistical Package for Social Sciences, version 20.0 which analyzed different factors and dependability of the variables. In present study, the researchers used different statistical tools. The table- 1 shows the demographics of female respondents i.e., age, qualification, residential status, marital status and monthly income. The table shows that a large percentage of female respondents i.e., $88.6 \%$ belong to 22-30 years age category while a small percentage of female respondents i.e., $11.4 \%$ belongs to $31-40$ years age category, $62.4 \%$ of the respondents are from graduate category while $29.5 \%$ are from under graduate level of education. As for as female respondents' residential status is concerned, the table shows that $89.6 \%$ female respondents are urban and $10.4 \%$ are rural female respondents. While $80.9 \%$ female respondents are single and $14.4 \%$ are married. $83.2 \%$ females' household income is below 20,000 while $8.7 \%$ females' household income remains 31-40 thousand.

Table 1: Demographics Profile of Female Respondents

\begin{tabular}{|l|c|c|c|c|c|}
\hline Description & Categories & $\mathrm{F}$ & $\%$ & Valid \% & Cuml \% \\
\hline \multirow{3}{*}{ Age } & $22-30$ & 264 & 88.6 & 88.6 & 88.6 \\
\cline { 2 - 6 } & $31-40$ & 34 & 11.4 & 11.4 & 100.0 \\
\hline \multirow{3}{*}{ Qualification } & Undergraduate & 88 & 29.5 & 29.5 & 29.5 \\
\cline { 2 - 6 } & Graduate & 186 & 62.4 & 62.4 & 91.9 \\
\cline { 2 - 6 } & Postgraduate & 24 & 8.1 & 8.1 & 100.0 \\
\hline \multirow{3}{*}{ Residential Status } & Urban & 214 & 89.6 & 89.6 & 89.6 \\
\cline { 2 - 6 } & Rural & 31 & 10.4 & 10.4 & 100.0 \\
\hline \multirow{3}{*}{ Monital Status } & Single & 241 & 80.9 & 80.9 & 80.9 \\
\cline { 2 - 6 } & Married & 43 & 14.4 & 14.4 & 95.3 \\
\cline { 2 - 6 } & Other & 14 & 4.7 & 4.7 & 100.0 \\
\hline & Below 20 thousand & 248 & 83.2 & 83.2 & 83.2 \\
\cline { 2 - 6 } & 21 to30 thousand & 24 & 8.1 & 8.1 & 91.3 \\
\cline { 2 - 6 } & 31 to 40 thousand & 26 & 8.7 & 8.7 & 100.0 \\
\hline
\end{tabular}

The table- 2 indicates the frequency of internet use by female respondents. The table indicates that $35.6 \%$ female respondents frequently use internet, $25.5 \%$ female respondents rarely use internet while $20.8 \%$ of the respondents never use internet.

Table 2: Use of Internet by Female Respondents

\begin{tabular}{|c|c|c|c|c|c|c|}
\hline Use & & Very Frequently & Frequently & Rarely & Never & Don't know \\
\hline Use of internet & $\mathrm{f}$ & 51 & 106 & 76 & 62 & 3 \\
\cline { 2 - 7 } & $\%$ & $17.1 \%$ & $35.6 \%$ & $25.5 \%$ & $20.8 \%$ & $1.0 \%$ \\
\hline
\end{tabular}


The table-3 shows the frequency of using internet from different places i.e., home, net café, office, public office, educational institutions and any other place. Table indicates that $71.8 \%$ female respondents use internet frequently at home and $7.7 \%$ female respondents rarely use internet at home, $70.8 \%$ female respondents never use internet at net café while small percentage of female respondents $14.7 \%$ frequently use internet at net café. A big percentage of female respondents $68.1 \%$ never use internet at office while small percentage of female respondents $12.4 \%$ frequently use internet at office.

As for as the public places are concerned $51.3 \%$ female respondents never use internet at public places and $13.4 \%$ female respondents frequently use internet at public places, $39.3 \%$ female respondents rarely use internet at educational institutions while $27.2 \%$ female respondents frequently use internet at educational institutions. Same table shows that $4.6 .0 \%$ female respondents never use internet from other places while $8.1 \%$ female respondents frequently use internet from other places.

Table 3: Different Places of Internet use by Female Respondents

\begin{tabular}{|l|c|c|c|c|c|c|}
\hline Places & & Very Frequently & Frequently & Rarely & Never & Don't know \\
\hline \multirow{2}{*}{ Home } & f & 93 & 121 & 23 & 61 & \\
\cline { 2 - 7 } & $\%$ & $31.2 \%$ & $40.6 \%$ & $7.7 \%$ & $20.5 \%$ & \\
\hline \multirow{2}{*}{ Net Café } & $\mathrm{f}$ & 24 & 18 & 36 & 211 & 9 \\
\cline { 2 - 7 } & $\%$ & $8.1 \%$ & $6.0 \%$ & $12.1 \%$ & $70.8 \%$ & $3.0 \%$ \\
\hline \multirow{2}{*}{ Office } & $\mathrm{f}$ & 20 & 17 & 55 & 203 & 3 \\
\cline { 2 - 7 } & $\%$ & $6.7 \%$ & $5.7 \%$ & $18.5 \%$ & $68.1 \%$ & $1.0 \%$ \\
\hline \multirow{2}{*}{ Public Places } & $\mathrm{f}$ & 14 & 26 & 105 & 153 & \\
\cline { 2 - 7 } & $\%$ & $4.7 \%$ & $8.7 \%$ & $35.2 \%$ & $51.3 \%$ & \\
\hline \multirow{2}{*}{$\begin{array}{l}\text { Educational } \\
\text { Institution }\end{array}$} & $\mathrm{f}$ & 34 & 47 & 117 & 95 & 5 \\
\cline { 2 - 7 } Any other & $\%$ & $11.4 \%$ & $15.8 \%$ & $39.3 \%$ & $31.9 \%$ & $1.7 \%$ \\
\cline { 2 - 7 } & $\%$ & 14 & 10 & 39 & 137 & 98 \\
\hline
\end{tabular}

The table- 4 shows the preferred source of shopping by the female respondents i.e., internet, call center services and retail store. Table shows that a big percentage of female respondents' $1^{\text {st }}$ preferred source for shopping is retail store $76.2 \%$. Same table shows that $2^{\text {nd }}$ preferred source by female respondents for shopping is call center services $53.4 \%$ and $3^{\text {rd }}$ preferred source of shopping by female respondents is internet $47.7 \%$.

Table 4: Preferred Source of Shopping by Female Respondents

\begin{tabular}{|l|c|c|c|c|}
\hline Preferred Source of Shopping & & $1^{\text {st }}$ & $2^{\text {nd }}$ & $3^{\text {rd }}$ \\
\hline \multirow{2}{*}{ Internet } & $\mathrm{f}$ & 54 & 102 & 142 \\
\cline { 2 - 5 } & $\%$ & $18.1 \%$ & $34.2 \%$ & $47.7 \%$ \\
\hline \multirow{2}{*}{ Call Centre Services } & $\mathrm{f}$ & 33 & 159 & 106 \\
\cline { 2 - 5 } & $\%$ & $11.1 \%$ & $53.4 \%$ & $35.6 \%$ \\
\hline \multirow{2}{*}{ Retail Stores } & $\mathrm{f}$ & 227 & 33 & 38 \\
\cline { 2 - 5 } & $\%$ & $76.2 \%$ & $11.1 \%$ & $12.8 \%$ \\
\hline
\end{tabular}

The table- 5 shows the frequency of social media sites used by female consumers. Results in this table show that $47.0 \%$ female respondents rarely used social media sites, $24.5 \%$ of the respondents used frequently, $14.8 \%$ respondents used very frequently, and $10.7 \%$ never used the social media sites. 
Table 5: Use of Social Media Sites by Female Respondents

\begin{tabular}{|l|c|c|c|c|c|c|}
\hline Description & & $\begin{array}{c}\text { Very } \\
\text { Frequently }\end{array}$ & Frequently & Rarely & Never & $\begin{array}{c}\text { Don't } \\
\text { know }\end{array}$ \\
\hline $\begin{array}{l}\text { Frequency of Using Social } \\
\text { Media Site }\end{array}$ & $\mathrm{f}$ & 44 & 73 & 140 & 32 & 9 \\
\cline { 2 - 7 } & $\%$ & $14 . .8 \%$ & $24.5 \%$ & $47.0 \%$ & $10.7 \%$ & $3.0 \%$ \\
\hline
\end{tabular}

The table-6 shows the frequency of online shopping using different sites of social communication/network i.e., Twitter, Facebook, Instagram, WhatsApp, Pinterest and any other site. Table shows that $51.7 \%$ never use Facebook for online shopping while small percentage of respondents $17.1 \%$ rarely use Facebook for online shopping, 37.6\% female respondents never use WhatsApp for online shopping and $28.2 \%$ female respondents rarely use WhatsApp for online shopping, $79.5 \%$ female respondents never use twitter for online shopping while $8.4 \%$ female respondents rarely use twitter for online shopping, $74.5 \%$ female respondents never use Instagram for online shopping while small percentage of respondents $12.1 \%$ frequently use Instagram for online shopping, 82.9\% female respondents never use Pinterest for online shopping and $1.7 \%$ female respondents rarely use Pinterest for online shopping, $61.7 \%$ female respondents never use any other social media site for online shopping and $7.4 \%$ female respondents frequently use other social media sites for online purchasing.

Table 6: Online Shopping by Female Respondents via Different Social Media Sites

\begin{tabular}{|l|c|c|c|c|c|c|}
\hline \multicolumn{2}{|l}{$\begin{array}{l}\text { Social Media Sites for Online } \\
\text { Shopping }\end{array}$} & $\begin{array}{c}\text { Very } \\
\text { Frequently }\end{array}$ & Frequently & Rarely & Never & $\begin{array}{c}\text { Don't } \\
\text { know }\end{array}$ \\
\hline \multirow{2}{*}{ Facebook } & $\mathrm{f}$ & 17 & 66 & 51 & 154 & 10 \\
\cline { 2 - 7 } & $\%$ & $5.7 \%$ & $22.1 \%$ & $17.1 \%$ & $51.7 \%$ & $3.4 \%$ \\
\hline \multirow{2}{*}{ WhatsApp } & $\mathrm{f}$ & 56 & 46 & 84 & 112 & \\
\cline { 2 - 7 } & $\%$ & $18.8 \%$ & $15.4 \%$ & $28.2 \%$ & $37.6 \%$ & \\
\cline { 2 - 7 } & $\%$ & 23 & 13 & 25 & 237 & \\
\hline \multirow{2}{*}{ Instagram } & $\mathrm{f}$ & $7.7 \%$ & $4.4 \%$ & $8.4 \%$ & $79.5 \%$ & \\
\cline { 2 - 7 } & $\%$ & $4.4 \%$ & $7.7 \%$ & $13.4 \%$ & $74.5 \%$ & \\
\hline \multirow{2}{*}{ Pinterest } & $\mathrm{f}$ & & 40 & 5 & 247 & 6 \\
\cline { 2 - 7 } & $\%$ & & $13.4 \%$ & $1.7 \%$ & $82.9 \%$ & $2.0 \%$ \\
\hline \multirow{2}{*}{ Any Other } & $\mathrm{f}$ & 10 & 22 & & 184 & 82 \\
\cline { 2 - 7 } & $\%$ & $3.4 \%$ & $7.4 \%$ & & $61.7 \%$ & $27.5 \%$ \\
\hline
\end{tabular}

The table-7 shows the frequency of using social media sites for shopping by female respondents. Table shows that a huge percentage of female respondents $47.0 \%$ never utilize social media sites for buying while small percentage of female respondents $18.0 \%$ frequently utilize social media sites for shopping.

Table 7: Frequency of Using Social Media Sites for Shopping by Female Respondents

\begin{tabular}{|l|c|c|c|c|c|c|}
\hline Description & & $\begin{array}{c}\text { Very } \\
\text { Frequently }\end{array}$ & Frequently & Rarely & Never & $\begin{array}{c}\text { Don't } \\
\text { know }\end{array}$ \\
\hline $\begin{array}{l}\text { Frequency of Using social media } \\
\text { sites for online Shopping }\end{array}$ & $\mathrm{f}$ & 9 & 45 & 90 & 140 & 14 \\
\cline { 2 - 7 } & $\%$ & $3.0 \%$ & $15.1 \%$ & $30.2 \%$ & $47.0 \%$ & $4.7 \%$ \\
\hline
\end{tabular}

The table- 8 shows the time spent on the online shopping by the female respondents i.e., they were asked about their time spent for $1 / 2$ hour, $1 \mathrm{hr}, 2 \mathrm{hrs}$, more than $2 \mathrm{hrs}$ and don't know. Table shows that $32.6 \%$ female respondents spend $1 / 2 \mathrm{hr}$ on online shopping and $5.4 \%$ female respondents spend $1 \mathrm{hr}$ on online shopping. 
Table 8: Time Spent on Online Shopping by Female Respondents

\begin{tabular}{|l|c|c|}
\hline Time spent on Online Shopping & f & $\%$ \\
\hline $1 / 2$ an Hour & 97 & $32.6 \%$ \\
\hline 1 Hour & 16 & $5.4 \%$ \\
\hline 2 Hours & 22 & $7.4 \%$ \\
\hline More than 2 Hours & 74 & $24.8 \%$ \\
\hline Don't Know & 89 & $28.9 \%$ \\
\hline
\end{tabular}

Table-9 shows the frequency of money spent by female respondents on online shopping i.e. below 10 thousand, 11 to 20 thousand, 21 to 30 thousand and 31 to 40 thousand. A big percentage of female respondents $76.5 \%$ spend below 10 thousand on online shopping while small percentage of female respondents $2.0 \%$ spend 31 to 40 thousand on online shopping.

Table 9: Money Spent on Online Shopping by Female Respondents

\begin{tabular}{|c|c|c|}
\hline Money Spend on Online Shopping Per Month & $\mathrm{f}$ & $\%$ \\
\hline Below 10 thousand & 228 & $76.5 \%$ \\
\hline 11 to 20 thousand & 64 & $21.5 \%$ \\
\hline 21 to 30 thousand & & \\
\hline 31 to 40 thousand & 6 & $2.0 \%$ \\
\hline
\end{tabular}

The table-10 shows the psychological factors which influence the behavior of the female respondents regarding online shopping i.e., security issues, privacy issues, overcharged, frauds and hackers, lack of trust over retailer and any other psychological factor. A large percentage of female respondents i.e., 59\% strongly agree that the security issues influence their behavior regarding online shopping while a small percentage of female respondents i.e., $11.1 \%$ are neutral with this statement. Regarding privacy issue, $64.4 \%$ female respondents are strongly agreed and $9.1 \%$ female are neutral with the statement that the privacy issues influence their behavior regarding online shopping. About the overcharging, $56.4 \%$ female respondents are strongly agree while $19.5 \%$ female respond was neutral about the statement that the products are overly charged which influence their behavior regarding online shopping. While asking about frauds and hacking, 54.7\% female respondents are strongly agree while small percentages of female respondents $19.5 \%$ are neutral with the statement that the problem of frauds and hacker influence their behavior regarding online shopping.

Table 10: Psychological Factors regarding Online Buying Behaviour of Female Respondents

\begin{tabular}{|l|c|c|c|c|c|c|}
\hline $\begin{array}{l}\text { Psychological } \\
\text { Element }\end{array}$ & & $\begin{array}{l}\text { Strongly } \\
\text { Disagree }\end{array}$ & Disagree & Neutral & Agree & $\begin{array}{c}\text { Strongly } \\
\text { Agree }\end{array}$ \\
\hline \multirow{2}{*}{ Security Issues } & $\mathrm{f}$ & 12 & 77 & 33 & 156 & 20 \\
\cline { 2 - 7 } & $\%$ & $4.0 \%$ & $25.8 \%$ & $11.1 \%$ & $52.3 \%$ & $6.7 \%$ \\
\hline \multirow{2}{*}{ Privacy Issues } & $\mathrm{f}$ & 12 & 67 & 27 & 172 & 20 \\
\cline { 2 - 7 } Overcharged & $\%$ & $4.0 \%$ & $22.5 \%$ & $9.1 \%$ & $57.7 \%$ & $6.7 \%$ \\
\cline { 2 - 7 } & $\mathrm{f}$ & 12 & 60 & 58 & 158 & 10 \\
\hline \multirow{2}{*}{ Frauds and Hackers } & $\mathrm{f}$ & 12 & 65 & 58 & 134 & 29 \\
\cline { 2 - 7 } $\begin{array}{l}\text { Lack of Trust over } \\
\text { Retailer }\end{array}$ & $\mathrm{f}$ & $4.0 \%$ & $21.8 \%$ & $19.5 \%$ & $45.0 \%$ & $9.7 \%$ \\
\cline { 2 - 7 } & $\%$ & $4.0 \%$ & $10.7 \%$ & $15.4 \%$ & $63.4 \%$ & $6.4 \%$ \\
\hline \multirow{2}{*}{ Any other } & $\mathrm{f}$ & 12 & 45 & 121 & 114 & 6 \\
\cline { 2 - 7 } & $\%$ & $4.0 \%$ & $15.1 \%$ & $40.6 \%$ & $38.3 \%$ & $2.0 \%$ \\
\hline
\end{tabular}


The same table also gives results about the trust on the retailer, that $69.8 \%$ female respondents are strongly agree and $14.7 \%$ female response was that they are strongly disagree with the statement that the lack of trust over the retailer influence their behavior regarding online shopping. Moreover, $40.3 \%$ female respondents are strongly agree while $19.1 \%$ female respondents are strongly disagree that the other psychological factors influence their behavior regarding online shopping.

\subsection{Descriptive Statistics}

The descriptive statistics display N, Mean and standard deviation for Age i.e., 21-30 and 3140. Table-11 indicates that there is no considerable difference in the mean score for age to the frequency of using internet. The mean for age group 21-30 is 2.48 and age group 31-40 is 2.40 with standard deviation is 0.46 and 0.06 respectively. Table indicates that $\mathrm{F}=1.526, \mathrm{t}=0.906$, and $\mathrm{p}=0.218$ is significant at 0.05 levels which shows there is noticeable difference between these two age groups, hence the hypothesis was accepted.

Table 11: Relationship between Age and Online Buying Behaviour

\begin{tabular}{|c|c|c|c|c|c|c|}
\hline Age & $\mathrm{N}$ & Mean & Standard Deviation & Std. Error Mean & $\mathrm{t}$ & Sig. \\
\hline $21-30$ & 264 & 2.4811 & 0.46855 & 0.02884 & \multirow{2}{*}{0.906} & \multirow{2}{*}{0.218} \\
\hline $31-40$ & 34 & 2.4050 & 0.39420 & 0.06760 & & \\
\hline
\end{tabular}

Table-12 highlights that descriptive statistics display N, Mean and standard deviation for Residential Status i.e., urban and rural. There is considerable difference in the mean score for residential status to the frequency of using internet. The mean for urban is 2.42 and mean for rural is 2.89 with standard deviation is 0.441 and 0.413 respectively. Table indicates that $\mathrm{F}=0.183, \mathrm{t}=-5.61$, and $\mathrm{p}=0.669$ is significant at 0.05 levels which shows there is a significant difference; Hence, the hypothesis is accepted.

Table 12: Relationship between Residential Status and Online Buying Behaviour

\begin{tabular}{|l|c|c|c|c|c|c|}
\hline Residential Status & N & Mean & SD & Std. Error Mean & t & Sig. \\
\cline { 1 - 5 } Urban & 267 & 2.4238 & 0.44150 & 0.02702 & \multirow{2}{*}{-5.610} & \multirow{2}{*}{0.669} \\
\hline Rural & 31 & 2.8908 & 0.41366 & 0.07430 & & \\
\hline
\end{tabular}

The table-13 indicates online buying behaviour of female respondents having different educational groups using one-way ANOVA. The table indicates $\mathrm{F}=2.838$ and $\mathrm{P}=.060<.05$ which depicts that there is noticeable difference among the female respondents regarding online buying behaviour having different educational group.

Table 13: Relationship between Qualification and Online Buying Behaviour of Females

\begin{tabular}{|l|c|c|c|c|c|}
\hline Description & Sum of Squares & Df & Mean Square & F & Sig. \\
\hline Between Groups & 1.190 & 2 & 0.595 & 2.838 & 0.060 \\
\hline Within Groups & 61.852 & 295 & 0.210 & & \\
\hline Total & 63.042 & 297 & & & \\
\hline
\end{tabular}

The table-14 indicates online buying behaviour of female respondents having different marital status using one-way ANOVA. The table indicates $\mathrm{F}=1.366$ and $\mathrm{P}=.257<.05$ which depicts that there is a considerable difference among the female respondents regarding online buying behaviour having different marital status. 
Table 14: Relationship between Marital Status and Online Buying Behaviour

\begin{tabular}{|l|c|c|c|c|c|}
\hline Description & Sum of Squares & Df & Mean Square & F & Sig. \\
\hline Between Groups & 0.579 & 2 & 0.289 & 1.366 & 0.257 \\
\hline Within Groups & 62.463 & 295 & 0.212 & & \\
\hline Total & 63.042 & 297 & & & \\
\hline
\end{tabular}

The table-15 indicates the online buying behaviour of the female respondents having different monthly income, using one-way ANOVA. The table indicates $\mathrm{F}=0.705$ and $\mathrm{P}=0.495<.05$ which depicts that there is noticeable difference among the female respondents regarding online buying behaviour having different monthly income.

Table 15: Relationship between Monthly Income and Online Buying Behaviour

\begin{tabular}{|l|c|c|c|c|c|}
\hline Description & Sum of Squares & Df & Mean Square & F & Sig. \\
\hline Between Groups & 0.300 & 2 & 0.150 & 0.705 & 0.495 \\
\hline Within Groups & 62.742 & 295 & 0.213 & & \\
\hline Total & 63.042 & 297 & & & \\
\hline
\end{tabular}

\subsection{Correlations}

Pearson's correlation coefficient was used to test the relationship between web content and online buying behaviour of the female respondents. Alpha was set at $\alpha=0.05$. The two-tailed test shows that correlation was significant $(\mathrm{r}=0.354, \mathrm{p}=0.000, \mathrm{n}=298)$. Therefore, the hypothesis that "there is significant relationship between web content and online buying behaviour of female respondents" is accepted.

Table 16: Relationship between Internet Exposure and Online Buying Behaviour of Females

\begin{tabular}{|l|l|c|c|}
\hline \multicolumn{2}{|l|}{ Description } & Frequency of Using Internet & Online Buying Behaviour \\
\hline \multirow{3}{*}{$\begin{array}{l}\text { Frequency of Using } \\
\text { Internet }\end{array}$} & Pearson Correlation & 1 & $0.354^{* *}$ \\
\cline { 2 - 4 } & Sig. (2-tailed) & & 0.000 \\
\cline { 2 - 4 } & $\mathrm{N}$ & 298 & 298 \\
\hline \multirow{2}{*}{$\begin{array}{l}\text { Online Buying } \\
\text { Behaviour }\end{array}$} & Pearson Correlation & $0.354^{* *}$ & 1 \\
\cline { 2 - 4 } & Sig. (2-tailed) & 0.000 & 298 \\
\cline { 2 - 4 } & $\mathrm{N}$ & 298 & \\
\hline \multirow{2}{*}{$* *$ Correlation is significant at the 0.01 level (2-tailed) } & \\
\hline
\end{tabular}

Pearson's correlation coefficient has been used to test the relationship between psychological factor and online purchasing behaviour of female respondents. Alpha was set at $\alpha=0.05$. The two-tailed test shows that correlation was significant ( $\mathrm{r}=-0.227^{* *}, \mathrm{p}=0.000, \mathrm{n}=298$ ). Therefore, the null hypothesis is rejected and the alternate hypothesis that "there is significant relationship between psychological factor and online buying behaviour or female respondents" is accepted.

Table 17: Psychological Factor and Online Buying Behaviour

\begin{tabular}{|l|l|c|c|}
\hline \multirow{2}{*}{ Description } & Psychological Factor & Online Buying Behaviour \\
\hline \multirow{3}{*}{$\begin{array}{l}\text { Psychological } \\
\text { Factor }\end{array}$} & Pearson Correlation & 1 & $-.227^{* *}$ \\
\cline { 2 - 4 } & Sig. (2-tailed) & & 0.000 \\
\cline { 2 - 4 } $\begin{array}{l}\text { Online Buying } \\
\text { Behaviour }\end{array}$ & $\mathrm{N}$ & $-0.227^{* *}$ & 298 \\
\cline { 2 - 4 } & Pearson Correlation & 0.000 & 1 \\
\cline { 2 - 4 } & Sig. (2-tailed) & 298 & 298 \\
\cline { 2 - 4 } **. Correlation is significant at the 0.01 level (2-tailed) &
\end{tabular}




\section{Conclusion}

It is concluded by the findings of the research paper that a big percentage of female respondents belong to the 22-30 years age category while a small percentage of female respondents belongs to the 31-40 years age category. Most of the female respondents are from the graduate level of education and urban areas having income below 20 thousand. It is also concluded by the findings that a big percentage of female respondents frequently use the internet and most of the female respondents use the internet at home while a small number of female respondents use the internet from educational institutions. Also, it is deduced that a big percentage of female consumers use the internet to get information. The research also indicates that the most preferred source of shopping is a retail store while a small number of female respondents shop through the internet.

Interestingly, results show that a huge number of female respondents use social media sites. It is deduced that the majority of female respondents spend less than $2 \mathrm{hrs}$ on the internet. It is concluded from the findings that a small number of female respondents use social media sites for online shopping. Different psychological factors are affecting the online buying attitude of female consumers such as security issues, privacy issues, overcharged, frauds and hackers, lack of trust over the retailer and any other, it is concluded from the results that most of the female respondents avoid online shopping because of the privacy issues and lack of trust over the retailer. In this research paper statistical tests such as One-way ANOVA test, T-Test and Pearson's Correlation test was applied by the researcher to check the significant relationship between given variables.

\subsection{Recommendations}

The findings of this research may not be comprehensive and an in-depth study may be needed using different directions and variables to validate these findings. However, based on the above analysis and discussion, following three are the recommendations of this study for future researchers:

a) Both male and female consumers shall be considered in future studies.

b) The retailers should to improve the privacy and safety concerns of the consumers.

c) The retailers should take measures regarding the trust building of the consumers.

\section{References}

Ajzen, I. (1991). The Theory of Planned Behaviour. Organizational Behaviour \& Human Decision Processes, 50(2), 179-211. https://www.dphu.org/uploads/attachements/books/books_4931_0.pdf

Ajzen, I., \& Fishbein. M. (1980). Understanding attitudes and predicting social behaviour. Prentice-Hall.

Akande, S. O. \& Bamise, O. F. (2017). The Role of School Library in Academic Motivation of Secondary School Students in Osun State, Nigeria. International Journal of Library Science, 6(1). 18-27. https://doi.org/10.5923/j.library.20170601.03

Akin-Adaramola, O. S. (2014). The Internet Usage among Secondary School Students: A Case Study on Labone Secondary School. Ashesi University College.

Acton, B., \& Koum, J. (2014). WhatsApp blog. http://blog.whatsapp.com/ 
Cotton, D. (2013). Rise of WhatsApp could slow Facebook's quest for mobile growth; little known in the U.S., WhatsApp has largely usurped SMS around the world. Advertising Age, 84, 23, 8-8.

Chen, Y. H., Hsu, I., \& Lin, C. C. (2010). Website attributes that increase consumer purchase intention: A conjoint analysis. Journal of Business Research, 63(9), 1007-1014. https://ideas.repec.org/a/eee/jbrese/v63yi9-10p1007-1014.html

December, J. (1996). Units of analysis for Internet communication. Journal of ComputerMediated Communication, 1(4), 0-0.

Enterpreneur.com (2008). Online advertising. http://www.entrepreneur.com/encyclopedia/term/82602.html

Geissler, G. L., \& Zinkhan, G. M. (1998). Consumer perceptions of the World Wide Web: An exploratory study using focus group interviews. Advances in Consumer Research, 25(1), 386-392.

Gardener, E. and Trivedi, M. (1998), A Communication Framework to Evaluate Sales Promotion Strategies. Journal of Advertising Research, 38(1), 67-71. https://www.thefreelibrary.com/A+Communications+Framework+to+Evaluate+Sal es+Promotion+Strategies-a053197687

Goldsmith, R. E. and Lafferty, B. A., (2002). Consumer Responses to Web sites and their Influence on Advertising Effectiveness, 12(4), 318-328. https://www.deepdyve.com/lp/emerald-publishing/consumer-response-to-web-sitesand-their-influence-on-advertising-0AlqwbgUVB

Gonzalez, P. (2013). The missing manual for Instagram - interview with Philippe Gonzalez, founder of Instagramers.com by the Mobilini Group. http://grupamobilni.pl/en/2013/08/missing-manual-instagram-interview-philippegonzalez-founder-instagramers-com/

Hoffman, D. L., Novak, T. P., \& Peralta, M. (1999). Building Consumer's Trust Online. Communication of the ACM, 42(4), 80-85. http://dx.doi.org/10.1145/299157.299175

Lee, H. J., \& Huddleston, P. T. (2010). An investigation of the relationships among domainspecific innovativeness, overall perceived risk and online purchase behaviour. International Journal of Electronic Marketing and Retailing, 3(1), 1-4. https://ideas.repec.org/a/ids/ijemre/v3y2010i1p1-4.html

Miller, R. \& Lammas, N. (2010). Social media and its implications for viral marketing. Asia Pacific Public Relations Journal, 11, 1-9.

Nazir, S., Tayyab, A., Sajid, A., \& Javed, I. (2012). How Online Shopping is Affecting Consumers Buying Behaviour in Pakistan? International Journal of Computer Science Issues (IJCSI), 9(3), 486-495. http://ijcsi.org/papers/IJCSI-9-3-1-486495.pdf

Pavlou, P. A. (2003). Consumer acceptance of electronic commerce: Integrating trust and risk with the technology acceptance model. International Journal of Electronic Commerce, 7(3), 101-134.

Pavlou, P. A., \& Fygenson, M. (2006). Understanding and predicting electronic commerce adoption: an extension of the theory of planned behaviour. MIS quarterly, 115-143. https://doi.org/10.2307/25148720

Parson, A. (2013). How Does Social Media Influence the Buying Behaviour of Consumers? [Online]. Business \& Entrepreneurship. http://yourbusiness.azcentral.com/socialmedia-influence-buying-behavior-consumers17017.html

Rehman, K. U., Rehman, I. U., Ashfaq, M., \& Ansari, S. (2011). Examining online Purchasing Behaviour: A case of Pakistan. International Proceedings of Economics Development \& Research, 5(2), 262-265. http://www.ipedr.com/vol5/no2/58-H10163.pdf 
Sulaiman, A., Mohezar, S., \& Rasheed, A. (2007). A Trust Model for E-Commerce in Pakistan: An Empirical Research. Asian Journal of Information Technology, 6(2), 192-199. https://medwelljournals.com/abstract/?doi=ajit.2007.192.199

Steelhouse (2012). Social Shopping 2012 Survey and Infographic. https://steelhouse.com/social-shopping-2012-survey/

Scott, M. (2013). 5 Surprising Social Media Statistics for 2013. Social media today website. http://socialmediatoday.com/docmarkting/1818611/five-surprising-socialmediastatistics-2013

Solomon, M. R. (2002). Consumer Behaviour: Buying, Having, and Being ( $5^{\text {th }}$ ed.). Prentice Hall.

Yu, T., \& Wu, G. (2007). Determinants of Internet Shopping Behaviour: An Application of Reasoned Behaviour Theory. International Journal of Management, 24(4), 744-762. https://search.proquest.com/openview/50ea549cb89c59d4e4dbafb0f8da7851/1?pqorigsite $=$ gscholar $\& \mathrm{cbl}=5703$

Zara, W. (2013). Oh, how Pinteresting! An introduction to Pinterest. Library Hi Tech News, 30(1), 1-4. https://doi.org/10.1108/07419051311320904 